\title{
The Right to Legal Aid in the Context of International Judicial Cooperation: Towards the Improvement of Equal Access to Justice for All?
}

\author{
Joana Apóstolo* \\ IPS_Innovative Prison Systems \\ Avenida Doutor Mário Moutinho 33-A, 1400-136 Lisbon, Portugal \\ Pedro Liberado \\ IPS_Innovative Prison Systems \\ Avenida Doutor Mário Moutinho 33-A, 1400-136 Lisbon, Portugal \\ Pedro das Neves \\ IPS_Innovative Prison Systems \\ Avenida Doutor Mário Moutinho 33-A, 1400-136 Lisbon, Portugal
}

\begin{abstract}
The present paper seeks to explore the present and prevailing obstacles to the respect of the right to legal aid, on the broader context of access to justice, against the background of the continuous efforts in European Union space for building a fair and inclusive society. We will first look into Directive 2016/1919 itself, as well as its context and provisions, framed in the context of the Europeanisation process in criminal matters. This first moment will allow us to better understand the prevailing critical issues hindering the full implementation of the Directive itself, and, consequently, its implications on restraining the fulfilment of right to legal aid. We will strive to comprehend how these obstacles, which stem from an ongoing - yet fundamentally unachieved integration project, are further densified by the practices of front-line professionals involved in the provision of legal aid. Ultimately, we conclude that further investment in cooperation, both at the national and European levels, is direly needed for achieving a fairer and more inclusive European Union.
\end{abstract}

Keywords: Legal Aid; European Union; Procedural Rights; Access to Justice; Judicial Cooperation.

DOI: $10.7176 /$ RHSS/11-12-04

Publication date:June $30^{\text {th }} 2021$

\section{Introduction}

Being involved in criminal justice procedures may entail tremendous challenges for a substantial number of individuals (United Nations Development Programme [UNDP] \& United Nations Office on Drugs and Crime [UNODC], 2016). In this context, the United Nations (UN) acknowledges that safeguarding procedural rights is not always easy, especially in what concerns legal aid and every other right to which it is intrinsically linked. Despite its recognition by the European Charter of Fundamental Rights of the European Union (European Union [EU], 2012), legal aid is still far from its ideal implementation in the EU space, even if the Directive (EU) 2016/1919 aims at closing existing gaps in this regard in the European Union space. Yet, and despite the efforts of the regional organisation in this regard, several elements hinder this right's full materialisation.

An imbrication of multi-level issues and difficulties, ranging from international divergences in the judicial (and legal aid provision) system(s) to embedded practices and limitations to first-line practitioners, create and entrench severe, long-lasting impacts. Before delving into the tension points related to this issue, it is first necessary to determine the interpretation of legal aid framing our paper. By legal aid, we refer not only to legal representation - such as the right to a lawyer ${ }^{1}$ (Cras, 2017) -, but also to the associated fulfilment of public access to law, in itself also linked to access to legal information, legal advice, and knowledge (Rice, 2009).

Nonetheless, ensuring legal representation does lie in the core concept of legal aid assistance, as its lack "may i) disadvantage the accused; ii) impact on counsel's ability to negotiate and prepare the case; and iii) hinder resolution attempts (plea negotiations and guilty pleas) at an early stage" (Flynn et al., 2016, p. 21). Going back to Directive (EU) 2016/1919, such importance is legitimately emphasised, as legal aid is defined as the "funding by a Member State of the assistance of a lawyer, enabling the exercise of the right of access to (it)" (p. 6), including "costs of the defence of suspects, accused persons and requested persons" (p. 2). Its qualification as a "right to having rights"2 (Martins, 2015, p. 9) is therefore due to its role as a fundamental prerequisite for equitable, humane and effective criminal justice systems, as pointed out by the United Nations Principles and

\footnotetext{
${ }^{1}$ Embodied by Directive (EU) 2013/48/EU (Directive 2013/48/EU, 2013).

${ }^{2}$ Translation by author. In the original "direito a ter direitos".
} 
Guidelines on Access to Legal Aid in Criminal Justice Systems (UNODC, 2013). Against this background, the adoption of the mentioned Directive goes hand in hand with the ever-increasing perception at the academic and policy levels of the links between justice, poverty and inequality, as noted by the UNDP and UNODC (2016).

\section{Directive (EU) 2016/1919: Context and provisions}

Insufficient access to legal aid carries devastating consequences to individuals involved as suspects or accused in criminal proceedings. Furthermore, it fundamentally calls into question the fairness and equity that should normatively characterise judicial systems. Acknowledging these central principles, the EU has been investing in furthering international judicial cooperation and multi-agency information sharing, in order to privilege the fulfilment of the right to legal aid. In this regard, the harmonisation of national criminal law through Community initiatives in procedural rights matters was especially pushed forward by the adoption of the Stockholm Roadmap (Presidency of the Council of the European Union, 2009; Ruggieri \& Militello, 2017).

The establishment of common minimum norms under the Roadmap sought, inter alias, to address the right to state-paid legal aid, and a number of other defence rights, in a strategy to balance the dominant focus on crossborder law enforcement which had, until then, marked the European integration project in criminal matters (Cape, Hodgson, \& Spronken, 2007; Ouwekerk, 2019). The political willingness to establish more consistent safeguards to the rights of suspects and accused persons in criminal proceedings is, therefore, clear in these initiatives. Addressing measure $\mathrm{C}$ of the Stockholm Roadmap (Council of the European Union, 2009), Directive (EU) 2016/1919 on legal aid for suspects and accused persons in criminal proceedings and for requested persons in European arrest warrant (EAW) proceedings (Directive 2016/1919/EU, 2016) aimed precisely at closing existing gaps in this regard. At its core, it seeks to support vulnerable individuals who lack sufficient financial resources to meet the costs of a court case or legal representation, while ensuring the fulfilment of Directive (EU) 2013/48 on the right to a lawyer. Unsurprisingly, 2016/1919 is generally recognised as a "step in the right direction" (Jackson \& Summers, 2018, p. 176).

Notwithstanding, several issues surrounding its full application point to the need for further harmonisation in EU Member States' judicial systems, so to ensure the full respect of procedural rights and, transversally, the right to a fair trial. In the context of the EU, the first noteworthy factors are blockades associated with differences in EU Member States' judicial systems, which directly undermine the Directive regarding legal aid. In fact, the continuous Europeanisation process in criminal matters has been referred to as the Europeanisation of national enforcement law, and not as the Europeanisation of criminal law itself (Vervaele, 2005). This is because, while determining substantial normative provisions which must be enforced at the national level, the European Commission (EC) - under the proportionality and subsidiarity principles - works closely with Member States, who maintain a degree of discretion when determining how such normative principles and minimum standards must be integrated into national law (European Parliamentary Research Service, 2016). Therefore, the convergence process promoted by the EU willingly strays away from the objective of direct and profound harmonisation of criminal justice systems.

We do not mean to here call into question the political and philosophical motivations underpinning the integration process in the area of criminal justice and procedural rights. Such motivations are, in fact, further reinforced by their description in terms of a functional approach, as a means to furthering cross-border cooperation and mutual trust ${ }^{1}$ (Presidency of the Council of the European Union, 2009). It is, however, also explicit in the wording of Directives arising from the Stockholm Roadmap ${ }^{2}$ that these legislative initiatives seek to achieve a more consolidated respect for procedural rights in the domestic sphere as well - since their provisions apply to all criminal proceedings, either transnational or domestic (Ouwekerk, 2019). Nevertheless, the foreseen national competence undermines the efforts for a harmonised application of procedural rights, leading to a number of shortcomings in the implementation of related Directives, as is the case of 2016/1919. As pointed by a survey developed by Fair Trials and EuroMoS (apud Fair Trials International, 2012) targeting lawyers practising in the EU, there are many operational issues which hinder the proper functioning of legal aid provision systems in EU Member States.

\section{Critical issues stemming from an ongoing yet unachieved integration project}

Effectively, and despite the important role of international institutions in pushing for the integration of polities, change will hardly be achieved without effective interaction between national and supranational instances (Jackson \& Summers, 2018). In fact, Directive (EU) 2016/1919 finds its inspiration in article 6(3) of the European Convention on Human Rights [ECHR], which does not put forward concrete guidelines for its translation into practice (Council of Europe [CoE], 1950) and, effectively, EU Member States enjoy the

\footnotetext{
${ }^{1}$ And as the reference to EAW procedings in Directive (EU) 2016/1919 also makes abundantly clear.

${ }^{2}$ Directive (EU) 2016/800; Directive (EU) 2016/1919; Directive (EU) 2016/343; Directive (EU) 2013/48; Directive (EU) 2012/13; Directive (EU) 2010/64 .
} 
responsibility of freely deciding on what means should be mobilised, according to individual national standards. While legal provisions concerning the right to legal aid are defined in all EU Member States' national legislation, the Directive's implementation is not always guaranteed. Ultimately, these circumstances further complicate the work of legal aid service providers who work towards guaranteeing the right to information and legal aid. And, at a broader scale, Sustainable Development Goal (SDG) 16, specifically its $3^{\text {rd }}$ target concerning the promotion of the rule of law at the national and international levels and ensure equal access to justice for all.

A relevant point of divergence deriving from this context relates to the minimum requirements for statefinanced legal aid. Hungary, Ireland and Czechia hold a means-test to assess the need for legal aid (Bulgarian Helsinki Committee [BHC], Hungarian Helsinki Committee [HHC], Human Rights Monitoring Institute [HRMI], Helsinki Foundation for Human Rights [HFHR], \& The Peace Institute [TPI], 2018; Fair Trials International, 2012). It is, however, worth highlighting that there is no common definition for the terms sufficient means, not by the ECHR, nor any other international instances (European Parliamentary Research Service, 2016), leading to further discrepancies and voiding the possibility of a truly European approach to ensuring the right to legal aid. Accountability and defence rights promoted by an Area of Freedom, Justice and Security are hindered in this diverse context, where the freedom of movement consequently leads to a higher number of EU-nationals involved in criminal proceedings in other Member States.

Additionally, some Member States foresee that legal costs associated with the defence may be recovered if the defendant is found to be guilty (European Parliamentary Research Service, 2016). Czechia's legal aid system, for example, imposes that suspects must repay associated legal costs if found guilty, as well as Bulgaria, Denmark, Sweden and Estonia (Fair Trials International, 2012; BHC, HHC, HRMI, HFHR, \& TPI, 2018). High legal fees are recognised as critical barriers to access to justice (UNDP \& UNODC, 2016), especially when considering the possibility of eventually having to bear the costs of legal aid, which may pressure them into waiving their right to a lawyer entirely (Fair Trials International, 2012; Fair Trials, 2018). In Finland, for instance, it is the lawyer who occasionally initiates legal aid applications. However, this caveat further complicates the process. Traditionally, the suspect might not even be in a position to afford a lawyer at all, besides the fact that the lawyers themselves are reluctant to initiate the proceedings without previous payment since the costs will not be covered by the state if the legal aid application is denied.

Moreover, Directive (EU) 2016/1919 imposes the provision of legal aid be available at the latest before questioning and even before relevant investigative and evidence-gathering acts begin (Directive 2016/1919/EU, 2016), a principle further supported by the European Union Agency for Fundamental Rights [FRA] (2019). This precept is upheld in England and Wales, which offer the right to legal advice as soon as the person is detained, independently from their financial capabilities (Cape, Hodgson, \& Spronken, 2007). Regardless, in Slovenia or Greece, suspects are usually not granted legal aid until they are brought before a judge (Fair Trials International, 2012; BHC, HHC, HRMI, HFHR, \& TPI, 2018). In addition, an analysis of the German and Finnish contexts shows that legal aid is only made available after the court's approval, therefore extending the duration of criminal proceedings and deepening its negative impacts in the lives of those involved. In turn, the Italian system entails complex bureaucratic procedures for the provision of legal aid, which usually cannot be provided while the suspect is under police custody, therefore voiding its purpose and the tasks judicial practitioners and law enforcement agents are responsible for (Fair Trials International, 2012). On the other hand, the Bulgarian system does foresee the right to legal aid to police detainees, despite being rarely exercised (BHC, HHC, HRMI, HFHR, \& TPI, 2018).

Another tier of complexity is therefore added to the role of legal aid providers in Cyprus, Finland and Greece, whose legal systems do not have an emergency lawyer system in place, meaning that legal aid service providers may only intervene at a later stage. This situation proves problematic by harming the quality of the legal aid service provider's work and, consequently, calling into question the fairness of criminal justice proceedings (Gruodyté \& Kirschner, 2016). Estonia, on the other hand, offers online legal assistance, which is available to all suspects (Fair Trials International, 2012), and Latvia launched a project pilot with the same goals (CoE, 2020). Conversely, other states such as Bulgaria and the Czechia do not allow suspects to independently choose their lawyer (Fair Trials International, 2012), thereby going against the precepts set by Directive (EU) 2013/48, which highlights the importance of considering the wishes and preferences of the suspect and accused person in the choice of the legal aid lawyer (Directive EU/2013/48).

As a result of the factors analysed above, suspects or accused people are often prevented or discouraged from exercising their rights, despite the fact that all individuals are entitled to the right to a fair trial, regardless of their possible sentence (Fair Trials, 2018). Considering this brief overview, we clearly understand that "international influences often do not suffice in themselves to effect change in practice, due to the significant obstacles to fairness that are intrinsic to legal cultures" (Jackson \& Summers, 2018, p. 176).

\section{Embedded practices: the role of practitioners involved in legal aid proceedings}

Besides the sheer availability and economic access to legal aid, a varied array of additional elements contribute 
to hindering the full implementation of the Directive in question and pose as obstacles to the work of professionals involved in legal aid proceedings. The work of professionals engaged in legal aid proceedings is another critical element in this regard. Notably because of the manifest shortcomings on the practitioner's side related to informing the individual of their rights. This is namely the case of Hungary, whose legal aid system also covers the fees and costs of the ex officio appointed defence council. However, suspects or accused people are often not adequately informed and cannot take advantage (BHC, HHC, HRMI, HFHR, \& TPI, 2018). The Bulgarian system shows some similarities in this regard, as police detainees are entitled to legal aid without any reimbursement provisions, but are again not informed of this fact by the law enforcement agents $(\mathrm{BHC}, \mathrm{HHC}$, HRMI, HFHR, \& TPI, 2018; Fair Trials International, 2012).

Moreover, it is important to highlight that the approach adopted by police officers often conduces to the violation of procedural rights, since, in several occasions, the individual in question is not assigned the status of suspect as a deliberate strategy aiming at avoiding triggering his/her rights. In addition, practitioners (including law enforcement agents) often make use of profoundly technical language, which is far from easy for suspects or accused persons to understand, hereby hindering the individual's understanding and access to legal aid.

On the other hand, in the Netherlands, even if the right to legal counsel is foreseen in early detention stages, the general practice dictates that the suspect has no right to the presence of a lawyer at police interrogation moments, a notion which is even typified in the law if the legal aid provider arrives later than two hours after the request. Eluding the general interpretation of 'reasonable period of time', this principle holds the suspect accountable for the absence of their legal aid provider, notably for reasons beyond their control (UNODC, 2014). At last, defendants often state not to have been involved at all in the choice of their legal representative, or that they were not even aware of this right (FRA, 2019) as a result of these poor practices by first-line practitioners. In this regard, the concern over the independence of the authority granting legal aid has been noted by the EU, namely in Hungary and Bulgaria ${ }^{1}$. While in the first case, legal aid is granted by the police at the pre-trial stage, in the second, it is the authorities who determine the appointer lawyer (European Parliamentary Research Service, 2016).

In the midst of such a complex field of work and the many shortcomings in the respect for the right to legal aid, the role of legal aid service providers takes on a renewed importance, despite the poor working conditions. Regardless, literature (BHC, HHC, HRMI, HFHR, \& TPI, 2018; European Parliamentary Research Service, 2016; Fair Trials International, 2012) highlights the lack of quality of their work and inadequacy of their skills factors inclusively mentioned in the Directive, which imposes the institution of quality control mechanisms (Directive 2016/1919/EU, 2016). In fact, it is not uncommon that individuals involved in criminal proceedings state not feeling "effectively represented by their assigned defence lawyers" (FRA, 2009, p. 67). On the other hand, a survey cited by UNDP and UNODC (2016, p. 122) notes that over $50 \%$ of the inquired in the Western Europe cluster state not having confidence in the quality of legal aid services provided in their country.

Seeking to minimise the negative consequences of these issues, the EC (2013) recommended the initial and continuous training of lawyers, paralegals and professionals who work with legal aid proceedings. However, as pointed by Fair Trials, it is not always easy to access this type of training programmes, considering that legal aid service providers receive substantially lower pay ${ }^{2}$ in comparison to their private colleagues and that they are often overburdened with cases (Fair Trials International, 2012; Fair Trials, 2018). In that regard, the Council of Bars and Law Societies of Europe (2018) states that, without State intervention towards fair remuneration, prevailing issues regarding the quality and efficiency of the defence and/or legal advice will inevitably prevail.

In this context, inclusive policies aiming to fight the marginalisation of already vulnerable groups must be at the core of transparent, equitable and fair criminal justice systems. As pointed out by the United Nations General Assembly (UNDP \& UNODC, 2016, p. 7), legal aid is crucial in "ensuring equal access to justice [...] and protecting the rights of persons with special needs, such as children, the elderly, people with disabilities or persons belonging to religious, linguistic or ethnic minority groups". Justiciable problems related to legal aid disproportionately affect the most vulnerable, and often lead to problem clustering, therefore strengthening the linkages between access to justice (and preceding legal aid) and poverty and social exclusion (OECD \& Open Society Foundations, 2019). A balanced approach must be adaptable and sensitive to when it comes to marginalised communities (e.g., lower socio-economic background, lower literacy levels, mentally ill individuals) (FRA, 2019; UNODC, 2013), thus guaranteeing the fairness of criminal judicial proceedings and the inclusion of all members of society, in pursuance of an efficient justice system.

However, it is not possible for professionals to guarantee the legal representation of vulnerable individuals in such a complex and diverse transnational context if they are not trained to take on a holistic approach. Adding

\footnotetext{
${ }^{1}$ See ECtHR case Zdravko Stanev v. Bulgaria, 2012.

2 The lack of investment in legal aid provision systems (and the consequent lower pay to legal aid service providers) is illustrated by the EU Member States cut-down in budget towards legal aid, as enforced by England and Wales, in pre-Brexit times, amounting to $350 £$ (Ministry of Justice, 2011).
} 
to this, the issue of legal aid provision to pre-trial detainees must be taken under consideration as well, since early detention stages are a critical period, fraught with the possibility of abuse and ill-treatment - ranging from demands for bribery to unlawful detention or coercion into waiving defence rights (Fair Trials \& Legal Experts Advisory Panel, 2015; UNODC, 2014). In fact, legal assistance provision should start even prior to pre-trial stage (e.g., suspect's interrogation by police officers), as the "evidence obtained through police questioning is crucial in a number of respects, [such as not only by] influenc[ing] whether or not charges are brought - and if they are, the terms in which these are framed -, [but also due to the] increasingly complex rules of evidence that apply to the pre-charge police investigation" (Kenny et al., 2016, p. 23). Unsurprisingly, the authors continue to stress "the evidence [...] gathered during the initial investigation and the police interrogation of the suspect, in particular, [...] shapes the trial - not only in terms of the charges prosecuted and the evidence presented, but also the reliability of that evidence" (p. 24). It should, therefore, be noted that the aforementioned concerns are in line with ECtHR considerations ${ }^{1}$, which yield that the fairness of the trial relies, imperatively, upon the fairness of the pre-trial procedures (e.g., police-led investigative phase).

On the other hand, the complexity of procedures felt in the mentioned national contexts often means that the individual faces initial hearings without a lawyer's assistance (Fair Trials, 2019). Moreover, individuals involved in proceedings related to the activation of judicial cooperation instruments (e.g., European Arrest Warrant [EAW]) are also especially vulnerable, namely in terms of potential violations of procedural rights and specifically in terms of access to legal aid. Despite the emphasis put by the Directive on the importance of legal aid to individuals involved in EAW procedures - and the notion of a "double right" to legal aid in EAW proceedings (Cras, 2017, p. 41) -, there are still substantial obstacles to its full respect.

\section{Ensuring access to legal aid in the context of judicial cooperation instruments}

The case of the EAW is especially illustrative for highlighting the emergence of additional issues for the fulfilment of the right to legal aid in its broad interpretation, in the context of international judicial cooperation. Namely, since it demands a closer interaction between very different judicial systems, first-line practitioners (e.g. police officers) and legal aid service providers (e.g., lawyers, paralegals), and therefore exacerbates pre-existing flaws. This mechanism aggravates the consequences from the existing discrepancies in the national legal aid provision systems, and the EU-co-funded EAW-Rights project's Final Report goes as far as recommending that there "should be EU-wide harmonisation of legal aid in relation to cross-border criminal cases" (Goldsmith, 2016, p. 7). For instance, in Germany, legal aid is often not available, due to the narrow test which is applied to EAW cases (JUSTICE, 2012).

However, even if convergence is hypothetically achieved in these matters, instruments such as the EAW pose additional obstacles, such as the respect for provisions such as the right to access to information in a language the suspect or accused person understands. Language barriers are possibly the most evident challenge to the right to information and, consequently, to the fulfilment of the right to legal aid. In Portugal, for instance, lawyers have expressed concern towards the appointment by the prosecution of interpreters, due to enabling access of client-lawyer privileged communications to a third party. Regardless, available interpreters and translators often lack the necessary competencies for court interpreting (JUSTICE, 2012).

Moreover, it is common that practitioners from the executing state neglect to inform the individual in question on his/her right to access legal assistance and legal aid in the issuing state, since "executing authorities do not feel competent to comment on laws in other states" (FRA, 2019, p. 14). Also, the specialisation and skills of the State-appointed lawyer, and even the judge and prosecutor in question, might not be adequate to the case under scope, especially in what concerns EAW-specific proceedings, as they might not present enough knowledge or in what concerns the judicial system of the issuing state (JUSTICE, 2012). These elements durably hinder the full respect of the right to information and subsequently the right to legal aid itself. Seeking to minimise negative consequences of these issues, the EC (2013) officially recommended the initial and continuous training of lawyers, paralegals and professionals who work with legal aid proceedings, an issue pointed out as well by the EAW Rights project's Final Report (Goldsmith, 2016). On the other hand, it is not always easy to access this type of training programmes, considering that legal aid service providers receive substantially lower pay than their private colleagues and that they are often overburdened with cases (Fair Trials International, 2012; Fair Trials, 2018). Bar associations are pointed as a part of a possible solution to this problem, notably through the delivery of mandatory accredited training specifically designed for EAW cases. However, many are reluctant to do so, as setting quality representation standards could be viewed as anticompetitive (JUSTICE, 2012).

Another relevant point concerns the details of dual legal representation: cross-border criminal lawyers face substantial obstacles to get in touch with each other, as simple elements such as contact details are often unavailable. However, even when efficiency is ensured in matters of dual representation, the noted multiplicity

\footnotetext{
${ }^{1}$ See ECtHR case Imbroscia v. Switzerland, 1993
} 
of practices often calls into question the availability of legal aid in the issuing state at the moment of the arrest in the executing state, a factor which evidently hampers the work of cross-border legal aid providers (Goldsmith, 2016). In fact, the Directive itself only imposes that provisional legal aid is ensured in the executing Member State, but not in the issuing one (Directive (EU) 2016/1919). In fact, only some EU courts (e.g., Denmark) acknowledge the need for expert advice in certain EAW cases, in order to guarantee a proper appreciation of the EAW request. In reality, the diverse moulds of the existing means tests in several other countries, such as Italy, are counter-productive in EAW cases, when foreigners are not able to prove their income at the early stages of the process (JUSTICE, 2012). Considering the critical relevance of quality legal assistance (and the preceding possibility to access legal aid) when assembling information to potentially challenge the surrender request, the lack of provisions towards the guarantee to legal aid in the issuing state is a pressing gap in need of bridging. Even more so in the frequent scenarios of poor defence by ex officio lawyers, at the early stages of the process (Fair Trials \& Legal Experts Advisory Panel, 2015; JUSTICE, 2012).

As a result of the analysed factors, suspects or accused people are often prevented or discouraged from exercising their rights, leading to the underrepresentation of vulnerable groups (Fair Trials International, 2012; Fair Trials, 2018; UNDP \& UNODC, 2016). In turn, SDG 16 is also undercut, seen as surveys point to a feeling of hopelessness to a degree of causing personal inertia to take action for seeking legal aid (OECD \& Open Society Foundations, 2019). Ultimately, the present situation actively prevents equal access to justice for all. On the other hand, the explored Directive is granted even further relevance when considering that its transposition limit was on May 25 ${ }^{\text {th }}, 2019$. Difficulties in its implementation are expected and will only become more evident over time. Therefore, this is an objectively appropriate moment to work towards the successful implementation of its provisions in EU Member States, not only by promoting the capacitation of judicial and legal practitioners but also law enforcement agents, who are at the centre of the Directive's successful implementation.

\section{Conclusion}

Throughout this paper we were able to present and explore existing differences in the system of legal aid provision in a number of EU Member States, its impact on a thorough Europeanisation of this defence right, and on the fulfilment of Directive (EU) 2016/1919. While the convergence of criminal law and procedural rights may not be fulfilled in the near future, and not even envisaged by the national governing elites, there is an evident willingness from the EU to achieve a higher degree of uniformisation, as previously highlighted. The inherently inconspicuous motivation of ensuring a higher degree of respect for fundamental rights is, in turn, reified by the need to respond to the growing intensity of judicial cooperation in EU space, and to the consequences deriving from the existing plethora of national practices, specifically concerning legal aid. Finally, law enforcement agents, judges, prosecutors and legal aid service providers seem to have dramatically different views regarding the respect of the right to information and the consequent access to legal aid, which in itself may be a sign of difficult cooperative relations between practitioners. Whereas the first three tend to state that suspects and accused people have been adequately informed in what regards their procedural rights, lawyers report on several challenges to an adequate transmission of information not only concerning the right to legal aid but also in what concerns the case or accusation as a whole (FRA, 2019). Such is, therefore, concurring with Jackson and Summers' (2018, p. 176) observation regarding the urgent need for "greater synergy between [not only] domestic [but also] international actors". Cooperation must be promoted, (inter)nationally, between law enforcement agents and judicial practitioners, in order to achieve systematic access to information and the respect of the right to a fair trial, along with training opportunities to the involved actors. Practitioners must also become more familiar with the Stockholm Roadmap, specifically Directive (EU) 2016/1919, which goes hand in hand with its provision regarding the training of staff involved in legal-aid decision making. Ultimately, a more substantial and increased commitment through concrete measures to grounding the right to legal aid would fundamentally contribute towards the fulfilment of SDG 16 on promoting peaceful and inclusive societies, providing access to justice for all and building effective, accountable and inclusive institutions at all levels - specifically the points regarding Rule of Law and equal access to justice, non-discriminatory laws and policies.

\section{References}

Bulgarian Helsinki Committee, Hungarian Helsinki Committee, Human Rights Monitoring Institute, Helsinki Foundation for Human Rights \& The Peace Institute. (2018). Right to a lawyer and to legal aid in criminal proceedings in five European jurisdictions: comparative report. Bulgarian Helsinki Committee.

Cape, E., Hodgson, J., \& Spronken, T. (2007). Procedural Rights at the Investigative Stage: Towards a Real Commitment to Minimum Standards. In E. Cape, J. Hodgson, T. Prakken, T. Sproken (Eds.), Suspects in Europe, Procedural Rights at the Investigative Stage on the Cirminal Process in Europe. Intersentia Antwerp-Oxford.

Council of Bars and Law Societies of Europe. (2018). CCBE Recommendations on legal aid. Council of Bars and Law Societies of Europe. 
https://www.ccbe.eu/fileadmin/speciality_distribution/public/documents/ACCESS_TO_JUSTICE/ATJ_Gui des_recommendations/EN_ATJ_20180323_CCBE-Recommendations-on-legal-aid.pdf

Council of Europe. (1950). European Convention for the Protection of Human Rights and Fundamental Freedoms, as amended by Protocols Nos. 11 and 14, ETS 5. Council of Europe.

Council of Europe. (2020, 12 October). Launch of the pilot project "One Stop legal aid Advice Service" in Latvia. Council of Europe European Commission for the Efficiency of Justice (CEPEJ). https://www.coe.int/en/web/cepej/home/-/asset_publisher/CO8SnxIjXPeD/content/launch-of-the-pilotproject-one-stop-legal-aid-advice-service-in-latvia?_101_INSTANCE_CO8SnxIjXPeD_viewMode=view/.

Council of the European Union. (2009). Resolution of the $\bar{C}$ ouncil of November 302009 on a Roadmap for strengthening procedural rights of suspected or accused persons in criminal proceedings. Official Journal of the European Union, C951/01.

Cras, S. (2017). The Directive on the Right to Legal Aid in Criminal and EAW Proceedings. Eucrim, 1, 34-44.

Directive 2013/48. Right to access a lawyer in criminal proceedings and in European arrest warrant proceedings, and on the right to have a third party informed upon deprivation of liberty and to communicate with third persons and with consular authorities while deprived of liberty. European Parliament, Council of the European Union.

Directive 2016/1919. Legal aid for suspects and accused persons in criminal proceedings and for requested persons in European arrest warrant proceedings. European Parliament, Council of the European Union.

European Commission. (2013). Commission Recommendation of 27 November 2013 on the right to legal aid for suspects or accused persons in criminal proceedings. Official Journal of the European Union, C378/11.

European Union Agency for Fundamental Rights. (2019). Rights in practice: Access to a lawyer and procedural rights in criminal and European arrest warrant proceedings. Publications Office of the European Union.

European Union. (2012). Charter of Fundamental Rights of the European Union. Official Journal of the European Union, C326/02.

Fair Trials International. (2012). The practical operation of legal aid in the EU. Fair Trials International.

Fair Trials \& Legal Experts Advisory Panel. (2015). Position paper on the proposed directive on provisional legal aid for suspects or accused persons deprived of liberty and legal aid in European arrest warrant proceedings. Fair Trials.

Fair Trials. (2018). EU Directive on Legal Aid for Suspects and Accused Persons in Criminal Proceedings and for Requested Persons in European Arrest Warrant Proceedings: Transposition Toolkit. Fair Trials.

Flynn, A., Hodgson, J., McCulloch, J., \& Naylor, B. (2016). Legal aid and access to legal representation: redefining the right to a fair trial. Melbourne University Law Review, 40(1), 1-33.

Goldsmith, J. (2016). EAW-Rights Final Report-Analysis of the implementation and operation of the European Arrest Warrant from the point of view of defence practitioners. Council of Bars and Law Societies of Europe.

Fair Trials. (2019). WHERE'S MY LAWYER? Making legal assistance in pre-trial detention effective. Fair Trials.

Gruodyte, E., \& Kirchner, S. (2016). Legal aid for intervenors in proceedings before the European Court of Human Rights. International Comparative Jurisprudence, 2(1), 36-44.

Jackson, J. D., \& Summers, S. J. (2018). Obstacles to Fairness in Criminal Proceedings: Individual Rights and Institutional Forms. Bloomsbury Publishing.

JUSTICE - advancing access to justice, human rights and the rule of law. (2012). European Arrest Warrants Ensuring an effective defence. JUSTICE.

Martins, R. A. (2015). Para uma defesa criminal efetiva: A assistência jurídica gratuita em Portugal e no Brasil. [Master's thesis]. Universidade de Coimbra.

Ministry of Justice. (2011). Reform of Legal Aid in England and Wales: The Government Response. Controller of Her Majesty's Stationery Office.

OECD/Open Society Foundations. (2019). Legal Needs Surveys and Access to Justice. OECD Publishing,

Ouwerkerk, J.W. (2019). EU Competence in the Area of Procedural Criminal Law: Functional vs. Self-standing Approximation of Procedural Rights and Their Progressive Effect on the Charter's Scope of Application (Editorial). European journal of crime, criminal law and criminal justice, 27(2), 89-96.

Presidency of the Council of the European Union. (2009). The Stockholm Programme - An open and secure Europe serving and protecting the citizens (17024/09). Council of the European Union.

Rice, S. (2009). A Human Right to Legal Aid. SSRN Electronic Journal.

Ruggieri F., Militello, E. (2017). Chronicle of 2016 EU law developments with criminal law and procedure implications. e-Revue Internationale de Droit Pénal.

United Nations Development Programme \& United Nations Office on Drugs and Crime. (2016). Global Study on Legal Aid - Global Report. UNDO and UNODC.

United Nations Office on Drugs and Crime. (2013). United Nations Principles and Guidelines on Access to Legal Aid in Criminal Justice Systems. Vienna: United Nations Office on Drugs and Crime. 
United Nations Office on Drugs and Crime. (2014). Early access to legal aid in criminal justice processes: a handbook for policymakers and practitioners. United Nations office on Drugs and Crime.

Vervaele, J. A. E. (2005). The Europeanisation of Criminal Law and the Criminal Law Dimension of European Integration. In P. Demaret, I. Govaere \& D. Hanf (Eds.), 30 Years of European Legal Studies at the College of Europe $=30$ ans d'études juridiques européennes au Collège d'Europe. Lang. 